\title{
Iron/copper-catalyzed C-C cross-coupling of aryl iodides with terminal alkynes
}

\author{
Chandra M. Rao Volla, Pierre Vogel * \\ Laboratoire de Glycochimie et Synthèse Asymétrique (LGSA), Swiss Federal Institute of Technology Lausanne (EPFL), Batochime, 1015 Lausanne, Switzerland
}

\section{A R T I C L E I N F O}

\section{Article history:}

Received 24 June 2008

Revised 23 July 2008

Accepted 29 July 2008

Available online 31 July 2008

\section{Keywords:}

Sonogashira-Hagihara coupling

Iron

Copper

Synergic effect

\begin{abstract}
A B S T R A C T
Synergic effect of iron and copper salts as catalysts for the Sonogashira-Hagihara cross-couplings of aryl iodides with terminal alkynes is demonstrated. High yields of cross-coupled products are obtained under conditions that are smoother than those using only CuI as catalyst. Furthermore no expensive or/and toxic ligand is required.
\end{abstract}

(c) 2008 Elsevier Ltd. All rights reserved.

\section{Introduction}

Aryl alkynes are important compounds for material sciences and medicinal chemistry. ${ }^{1}$ These compounds are best obtained by the Sonogashira-Hagihara cross-coupling reaction of terminal alkynes with aryl halides or triflates, originally using palladium catalysts together with phosphine or diamine ligands. ${ }^{2}$ Transition metal-free Sonogashira-Hagihara reactions of aromatic iodides and bromides with terminal alkynes have been reported, but they require very high temperature, phase-transfer catalyst, and microwave activation. Furthermore, they are limited to aromatic alkynes. $^{3}$ Sonogashira-Hagihara cross-couplings have been reported using less harsh conditions in the presence of copper, ${ }^{4}$ ruthenium, ${ }^{5}$ or nickel ${ }^{6}$ catalysts and adequate ligands. Li and coworkers ${ }^{7}$ reported that $\mathrm{CuI} / \mathrm{DABCO}$ is an effective catalyst for Sonogashira-Hagihara cross-couplings of aryl halides and vinyl halides. Highly dispersed $\mathrm{Cu}$ metal on alumina is a good catalyst for the cross-coupling of aryl iodides with phenylacetylene. ${ }^{8} \mathrm{CuI} /$ ligand couples are good catalysts for $\mathrm{C}-\mathrm{C}, \mathrm{C}-\mathrm{N}$, and C-O Ullmann-type coupling reactions. ${ }^{9}$ The discovery in 1954 by Kharasch and Reinmuth, ${ }^{10}$ then in 1971 by Tamura and Kochi ${ }^{11}$ that Grignard reagents and alkyl halides can be cross-coupled in the presence of iron catalysts has stimulated several studies toward the substitution of expensive and toxic transition metals and ligands by iron catalysts in $\mathrm{C}-\mathrm{C}$ bond forming reactions. ${ }^{12-18}$ Iron salts are cheap, non-toxic, and environmentally benign. ${ }^{19} \mathrm{~A}$ recent report by Bolm and co-workers ${ }^{20}$ on iron-catalyzed Sonogashira reaction urges us to present our own studies on this topic. ${ }^{21}$ Aromatic iodides and

\footnotetext{
* Corresponding author. Tel.: +41 2169393 71; fax: +41 216939350

E-mail address: pierre.vogel@epfl.ch (P. Vogel).
}

terminal alkynes undergo $\mathrm{C}-\mathrm{C}$ cross-coupling reactions in the presence of iron salt and CuI as catalysts and under relatively smooth conditions that do not require the presence of expensive or toxic ligand. Iron-catalysis has been recently extended to allylic alkylation, allylic aminations, ${ }^{22}$ and carbon-heteroatom cross-coupling reactions. ${ }^{21,23,24}$

\section{Results}

Our initial attempts used 4-iodotoluene and phenylacetylene as the coupling partners in the presence of iron(III) acetylacetonate and copper(I) iodide, without any external ligand. The reaction was carried out in DMF at $140{ }^{\circ} \mathrm{C}$ with $\mathrm{Cs}_{2} \mathrm{CO}_{3}$ as the base of choice (Table 1). We find that the reaction is completed in $36 \mathrm{~h}$ giving 1(4-methylphenyl)-2-phenylethyne in 93\% yield (Table 1, entry 1 ). The crucial roles played by both iron and copper salts were clear as reactions done in the absence of either iron or copper led only to low yields of product (entries 2 and 3 ). Without iron and copper catalysts the coupling did not occur at all (entry 4), thus demonstrating the synergic effect of iron and cuprous salts. This type of synergic effect of $\mathrm{Fe} / \mathrm{Cu}$ has been disclosed in the arylmagnesation of internal alkynes. ${ }^{25}$ Reaction time was somewhat shorter in DMSO (entry 6 ) or NMP ( $N$-methylpyrrolidinone) (entry 7$)$. The beneficial effect of NMP was also observed for other iron-catalyzed C-C coupling reaction. ${ }^{13,18}$ Among several iron salts, (Table 1, entries 9-13) iron(III)acetylacetonate appeared to be the best catalyst. Nakamura has shown the importance of fluoride ion in ironcatalyzed Corriu-Kumada coupling reaction. ${ }^{17 \mathrm{c}}$ In our case $\mathrm{FeF}_{3} \cdot\left(\mathrm{H}_{2} \mathrm{O}\right)_{3}$ (entry 10) was not as efficient as $\mathrm{Fe}(\mathrm{acac})_{3}$. To our surprise, although $\mathrm{FeCl}_{3}+\mathrm{CuI}$ (entry 9) did catalyze the reaction almost as well as $\mathrm{Fe}(\mathrm{OAc})_{2}+\mathrm{CuI}$ (entry 12 ), $\mathrm{FeCl}_{2}+\mathrm{CuI}$ (entry 11), 
Table 1

Iron/copper-catalyzed coupling of 4-iodotoluene with phenylacetylene
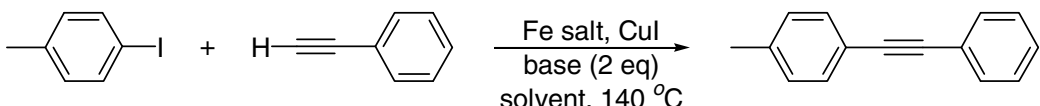

solvent, $140{ }^{\circ} \mathrm{C}$

\begin{tabular}{|c|c|c|c|c|c|c|c|}
\hline Entry & Fe source $(\mathrm{mol} \%)$ & $\mathrm{CuI}(\mathrm{mol} \%)$ & Ligand (15 mol \%) & Base & Solvent & Time (h) & Yield $^{\mathrm{a}}(\%)$ \\
\hline 1 & $\mathrm{Fe}(\mathrm{acac})_{3}(10)$ & 10 & - & $\mathrm{Cs}_{2} \mathrm{CO}_{3}$ & DMF & 36 & 93 \\
\hline 2 & $\mathrm{Fe}(\mathrm{acac})_{3}(10)$ & - & - & $\mathrm{Cs}_{2} \mathrm{CO}_{3}$ & DMF & 48 & - \\
\hline 3 & - & 10 & - & $\mathrm{Cs}_{2} \mathrm{CO}_{3}$ & DMF & 48 & 6 \\
\hline 4 & - & - & - & $\mathrm{Cs}_{2} \mathrm{CO}_{3}$ & DMF & 36 & - \\
\hline 5 & $\mathrm{Fe}(\mathrm{acac})_{3}(10)$ & 10 & - & $\mathrm{Cs}_{2} \mathrm{CO}_{3}$ & DMF & 2.5 & $94^{\mathrm{b}}$ \\
\hline 6 & $\mathrm{Fe}(\mathrm{acac})_{3}(10)$ & 10 & - & $\mathrm{Cs}_{2} \mathrm{CO}_{3}$ & DMSO & 21 & 87 \\
\hline 7 & $\mathrm{Fe}(\mathrm{acac})_{3}(10)$ & 10 & - & $\mathrm{Cs}_{2} \mathrm{CO}_{3}$ & NMP & 20 & 95 \\
\hline 8 & $\mathrm{Fe}(\mathrm{acac})_{3}(5)$ & 10 & - & $\mathrm{Cs}_{2} \mathrm{CO}_{3}$ & NMP & 48 & 68 \\
\hline 9 & $\mathrm{FeCl}_{3}(10)$ & 10 & - & $\mathrm{Cs}_{2} \mathrm{CO}_{3}$ & NMP & 48 & 55 \\
\hline 10 & $\mathrm{FeF}_{3} \cdot 3 \mathrm{H}_{2} \mathrm{O}(10)$ & 10 & - & $\mathrm{Cs}_{2} \mathrm{CO}_{3}$ & NMP & 48 & 76 \\
\hline 11 & $\mathrm{FeCl}_{2}(10)$ & 10 & - & $\mathrm{Cs}_{2} \mathrm{CO}_{3}$ & NMP & 48 & Traces \\
\hline 12 & $\mathrm{Fe}(\mathrm{OAC})_{2}(10)$ & 10 & - & $\mathrm{Cs}_{2} \mathrm{CO}_{3}$ & NMP & 48 & 61 \\
\hline 13 & $\mathrm{Fe}(\mathrm{OAC})_{2}(10)$ & - & - & $\mathrm{Cs}_{2} \mathrm{CO}_{3}$ & NMP & 48 & - \\
\hline 14 & $\mathrm{Fe}(\mathrm{acac})_{3}(7)$ & 10 & TMEDA & $\mathrm{Cs}_{2} \mathrm{CO}_{3}$ & NMP & 40 & 89 \\
\hline 15 & $\mathrm{Fe}(\mathrm{acac})_{3}(7)$ & 10 & DMEDA & $\mathrm{Cs}_{2} \mathrm{CO}_{3}$ & NMP & 40 & 85 \\
\hline 16 & $\mathrm{Fe}(\mathrm{acac})_{3}(7)$ & 10 & HMTA & $\mathrm{Cs}_{2} \mathrm{CO}_{3}$ & NMP & 36 & 91 \\
\hline 17 & $\mathrm{Fe}(\mathrm{acac})_{3}(10)$ & 10 & - & $\mathrm{K}_{3} \mathrm{PO}_{4}$ & NMP & 48 & 71 \\
\hline 18 & $\mathrm{Fe}(\mathrm{acac})_{3}(10)$ & 10 & - & $\mathrm{Et}_{3} \mathrm{~N}$ & NMP & 21 & Traces \\
\hline
\end{tabular}

a Yields were determined after flash chromatography.

b Reaction was done in a microwave reactor. acac = Acetylacetonate, $\mathrm{DMF}=$ dimethylformamide, DMSO $=$ dimethylsulfoxide, $\mathrm{NMP}=\mathrm{N}$-methylpyrrolidone, TMEDA = N,N,N,$N^{\prime}$-tetramethylethylenediamine, DMEDA = N,N'-dimethylethylenediamine, HMTA = hexamethylenetetramine.

$\mathrm{Fe}(\mathrm{OAc})_{2}$ alone (entry 13 ) did not catalyze it. This shows the importance of the oxygenated $\sigma$-ligands of the iron salt. Cahiez et al. reported the beneficial effect of TMEDA and HMTA as additives in iron-catalyzed cross-coupling of alkyl halides with Grignard reagents. ${ }^{13 \mathrm{~d}, \mathrm{e}}$

Addition of external ligands such as $\mathrm{Et}_{3} \mathrm{~N}$, TMEDA, DMEDA, or HMTA did not help the reaction (entries 14-16). Substitution of $\mathrm{Cs}_{2} \mathrm{CO}_{3}$ by $\mathrm{K}_{3} \mathrm{PO}_{4}$ retarded somewhat the reaction, whereas $\mathrm{Et}_{3} \mathrm{~N}$ as base alone gave the product only in trace amounts (entries 17 and 18). When the reaction was carried out in $m$-xylene in the presence of 1 equiv of NMP, low yield of the coupling product was observed. Although the reaction takes $20 \mathrm{~h}$ for completion, the reaction time can be greatly decreased by using a microwave reactor ( $2.5 \mathrm{~h}$ for nearly same yields) (Table 1 , entry 5 ). Our best conditions (Table 1 , entry 7 ) were then applied to the cross-coupling of a variety of terminal acetylenes with 4-iodotoluene (Table 2 ). In most cases, the reaction was over in ca $20 \mathrm{~h}$ at $140{ }^{\circ} \mathrm{C}$ except for (4-methoxyphenyl)acetylene which required $36 \mathrm{~h}$ (entry 10)

Table 2

Iron/copper-catalyzed coupling of various terminal alkynes with 4-iodotoluene<smiles>[R]C#C[IH+]</smiles>

$\mathrm{Fe}(\mathrm{acac})_{3}(10 \mathrm{~mol} \%), \mathrm{Cul}(10 \mathrm{~mol} \%)$ $\mathrm{Cs}_{2} \mathrm{CO}_{3}$ (2 equiv.), NMP, $140{ }^{\circ} \mathrm{C}$

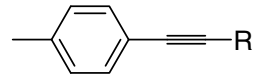

\begin{tabular}{rlll}
\hline Entry & $\mathrm{R}$ & Time $(\mathrm{h})$ & Yield $^{\mathrm{a}}(\%)$ \\
\hline 1 & Phenyl & 20 & 95 \\
2 & Phenyl & 2.5 & $94^{\mathrm{b}}$ \\
3 & 4-Methylphenyl & 20 & 92 \\
4 & n-Octyl & 18 & 91 \\
5 & $n$-Hexyl & 18 & 96 \\
6 & t-Butyl & 18 & 86 \\
7 & n-Butyl & 18 & 87 \\
8 & 3-Pyridyl & 21 & 92 \\
9 & 4-Methoxyphenyl & 36 & 79 \\
10 & Cyclohexen-1-yl & 20 & 94 \\
\hline
\end{tabular}

a Yields of isolated products after flash chromatography.

b Reaction was done in a microwave reactor. for a $79 \%$ yield. A wide variety of terminal acetylenes with aryl, alkyl, 3-pyridinyl, and cyclohexen-1-yl substituents gave the corresponding products of cross-coupling in good to excellent yields.

In order to extend the scope of the reaction further, we explored the cross-coupling of various electrophilic partners with phenylacetylene (Table 3). Apart from 4-iodonitrobenzene all aryl iodides assayed led to good yields of isolated products. With 4-bromo-, 4chlorotoluene, and 4-methylbenzenesulfonyl chloride (entries 24) no product of cross-coupling could be observed. In the latter case, the sulfonyl chloride decomposed rapidly giving a small amount of products of homocoupling. Interestingly, the cross-coupling reaction was successful for electron-poor (entries 6-10, 15

Table 3

Iron/copper-catalyzed cross-coupling of aryl halides with phenylacetylene

$$
\mathrm{R}^{\prime}-\mathrm{X}+\mathrm{H}=\mathrm{Ph} \quad \begin{gathered}
\mathrm{Fe}(\mathrm{acac})_{3}(10 \mathrm{~mol} \%), \\
\stackrel{\mathrm{Cul}(10 \mathrm{~mol} \%)}{\mathrm{Cs}_{2} \mathrm{CO}_{3}(2 \text { equiv. }),} \\
\mathrm{NMP}, 140^{\circ} \mathrm{C}
\end{gathered} \mathrm{R}-\mathrm{Ph}
$$

\begin{tabular}{rllll}
\hline Entry & $\mathrm{R}^{\prime}$ & $\mathrm{X}$ & Time (h) & Yield $^{\mathrm{a}} \%$ \\
\hline 1 & 4-Methylphenyl & $\mathrm{I}$ & 20 & 95 \\
2 & 4-Methylphenyl & $\mathrm{Br}$ & 24 & 0 \\
3 & 4-Methylphenyl & $\mathrm{Cl}$ & 24 & 0 \\
4 & 4-Methylphenyl & $\mathrm{SO}_{2} \mathrm{Cl}$ & 24 & $0^{\mathrm{b}}$ \\
5 & Phenyl & $\mathrm{I}$ & 20 & 94 \\
6 & 4-Fluorophenyl & $\mathrm{I}$ & 18 & 96 \\
7 & 4-(Trifluoromethyl)phenyl & $\mathrm{I}$ & 18 & 98 \\
8 & 4-Nitrophenyl & $\mathrm{I}$ & 24 & $0^{\mathrm{c}}$ \\
9 & 4-Cyanophenyl & $\mathrm{I}$ & 18 & 87 \\
10 & 4-Acetylphenyl & $\mathrm{I}$ & 18 & 89 \\
11 & 2-Methylphenyl & $\mathrm{I}$ & 20 & 91 \\
12 & 3-Methylphenyl & $\mathrm{I}$ & 20 & 85 \\
13 & 1-Naphthyl & $\mathrm{I}$ & 20 & 93 \\
14 & 4-Methoxyphenyl & $\mathrm{I}$ & 36 & 83 \\
15 & 4-Bromophenyl & $\mathrm{I}$ & 18 & 96 \\
16 & 4-Chlorophenyl & $\mathrm{I}$ & 18 & 97 \\
\hline
\end{tabular}

a Yield of isolated products after flash chromatography.

Starting material was decomposed after $3 \mathrm{~h}$ under the reactions conditions, small amount of homocoupling of phenylacetylene was observed.

c Starting material was decomposed to give a mixture of products (nitrobenzene and aniline). 
16) as well as for electron-rich aryl iodides (entries 11-14). 4-Iodonitrobenzene decomposed immediately under our reaction conditions to give a mixture containing nitrobenzene and aniline and no trace of the desired product of cross-coupling (entry 8). All products of $\mathrm{C}-\mathrm{C}$ coupling were obtained pure and were identical to authentic samples $\left({ }^{1} \mathrm{H},{ }^{13} \mathrm{C}\right.$ NMR spectra).

\section{Discussion}

More studies are necessary to approach possible mechanisms of our cross-coupling reactions. Under our conditions that do not use any ligand apart from solvent (DMF, DMSO, and NMP), we find that $\mathrm{CuI}$ alone catalyzes the homo-coupling very slowly (Table 1, entry 3 ). On addition of a Fe salt, the reaction is accelerated significantly. It is known that $\mathrm{CuI} / \mathrm{Na}_{2} \mathrm{CO}_{3}$ catalyzes the homo-coupling of terminal alkynes with aryliodonium salts. ${ }^{26}$ Thus, a possible role of the Fe salt is to activate the oxidative addition of CuI, or $\mathrm{Cu}$ acetylide intermediate (that could arise from $\mathrm{Cu}(\mathrm{II})$ salt intermediates according to the Bohlmann mechanism ${ }^{27}$ ), onto aryl iodide by coordination to the iodo moiety of ArI. Alternatively, the activation could involve a SET from ArI to the Fe(III) salt giving $\mathrm{FeX}_{3}^{-}$and the corresponding radical-cation $\mathrm{ArI}^{+} \cdot$ that undergoes a faster oxidative addition than neutral ArI. The formation of the $\mathrm{Ar}-\mathrm{Cu}(\mathrm{I})$-acetylide intermediates might be preceded by the formation of $\mathrm{Cu}$ acetylides, or by addition of ArCuI to the terminal acetylenes, ${ }^{28}$ followed by base-induced $\mathrm{HI}$ elimination. The nature of the base is essential as $\mathrm{Et}_{3} \mathrm{~N}$ does not induce the cross-coupling reaction as well as $\mathrm{Cs}_{2} \mathrm{CO}_{3}$.

\section{Conclusion}

In summary, we have developed new conditions for the $\mathrm{C}-\mathrm{C}$ cross-coupling of aromatic iodides with terminal acetylenes using cheap, non-toxic, commercially available iron salts, and CuI as catalysts. No toxic or/and expensive ligand is required for the metallic catalysts as NMP (or DMSO, DMF), the solvent, is probably playing the role of ligand. The synergic effect of $\mathrm{Fe}$ and $\mathrm{Cu}$ salts is thus demonstrated in Sonogashira-Hagihara reaction. ${ }^{29,30}$ Furthermore, they are high yielded and can be run in shorter time using microwave. They should find economical applications in the fields of material sciences and medicinal chemistry.

\section{Experimental Procedure}

In a sealable tube dried under vacuum were placed the corresponding ArI (if it is a solid) (1 equiv), $\mathrm{Fe}(\mathrm{acac})_{3}$ ( $\left.10 \mathrm{~mol} \%\right), \mathrm{CuI}$ ( $10 \mathrm{~mol} \%$ ), and $\mathrm{Cs}_{2} \mathrm{CO}_{3}$ (2 equiv) (glove box). Then, the tube was sealed with the cap. The tube was connected to a vacuum line and filled with $\operatorname{Ar}$ ( 3 times), NMP ( $2 \mathrm{~mL}$ ), the corresponding iodide (if it is a liquid) (1 equiv), and the corresponding alkyne ( 2 equiv) were added. The reaction mixture was stirred at $140{ }^{\circ} \mathrm{C}$ for the time mentioned. After cooling to room temperature, the mixture was diluted with diethyl ether, and water was added. The aqueous layer was extracted again with ether $\left(20 \mathrm{~mL}^{*} 3\right.$ times). The combined organic phases were dried $\left(\mathrm{MgSO}_{4}\right)$, filtered, and concentrated under reduced pressure (rotavap). The residue was purified by flash chromatography on silica gel.

\section{Experimental Procedure for reactions under microwave irradiation}

In a $5 \mathrm{~mL}$ microwave tube were placed iodotoluene $(0.2 \mathrm{~g}$, $0.92 \mathrm{mmol}, 1$ equiv), $\mathrm{Fe}(\mathrm{acac})_{3}$ ( $\left.32 \mathrm{mg}, 0.09 \mathrm{mmol}, 10 \mathrm{~mol} \%\right)$, CuI (18 $\mathrm{mg}, 0.09 \mathrm{mmol}, 10 \mathrm{~mol} \%$ ), and $\mathrm{Cs}_{2} \mathrm{CO}_{3}(0.6 \mathrm{~g}, 1.84 \mathrm{mmol}$, 2 equiv) (glove box). Then, the tube was sealed with the cap. The tube was connected to a vacuum line and filled with $\mathrm{Ar}$ (3 times), NMP ( $2 \mathrm{~mL})$ and phenylacetylene $(0.2 \mathrm{~mL}, 1.84 \mathrm{mmol}, 2$ equiv) were added. The reaction mixture was stirred in a microwave reactor at $140{ }^{\circ} \mathrm{C}$ for $2.5 \mathrm{~h}$. After cooling to room temperature, the mixture was diluted with diethyl ether, and water was added. The aqueous layer was extracted again with ether $\left(20 \mathrm{~mL}^{*} 3\right.$ times). The combined organic phases were dried $\left(\mathrm{MgSO}_{4}\right)$, filtered, and concentrated under reduced pressure (rotavap). The residue was purified by flash chromatography on silica gel.

\section{Acknowledgement}

We are grateful to the Swiss National Science Foundation (Bern) and the Roche Research Foundation (Basel). We also thank F. Sepulveda and M. Rey for their technical help.

\section{References and notes}

1. (a) Sonogashira, K. In Metal-Catalyzed Cross-Coupling Reactions; Diedrich, F., de Meijere, A., Eds.; Wiley-VCH: Weinheim, 2004; Vol. 1, p 319; (b) Sonogashira, K. In Handbook of Organopalladium Chemistry for Organic Synthesis; Negishi, E., de Meijere, A., Eds.; Wiley-Interscience: New York, 2002; p 493. and references therein.

2. For reviews: (a) Hassan, J.; Sevignon, M.; Gozzi, Ci.; Schulz, E.; Lemaire, M. Chem. Rev. 2002, 102, 1359; (b) Chinchilla, R.; Najera, C. Chem. Rev. 2007, 107, 874-922 and references therein.

3. (a) Appukkutan, P.; Dehaen, W.; Eycken, E. V. D. Eur. J. Org. Chem. 2003, 47134716; (b) Leadbeater, N. E.; Marco, M.; Tominack, B. J. Org. Lett. 2003, 5, 39193922 .

4. (a) Okuro, K.; Furuune, M.; Miura, N.; Nomura, M. Tetrahedron Lett. 1992, 33, 5363-5364; (b) Okuro, K.; Furuune, M.; Enna, M.; Miura, M.; Nomura, M. J. Org. Chem. 1993, 58, 4716-4721; (c) Gujadhur, R. K.; Bates, C. G.; Venkataraman, D. Org. Lett. 2001, 3, 4315-4317; (d) Bates, C. G.; Saejueng, P.; Murphy, J. M.; Venkataraman, D. Org. Lett. 2002, 4, 4727-4729; (e) Wang, J.-X.; Liu, Z.; Hu, Y.; Wei, B.; Kang, L. Synth. Commun. 2002, 32, 1937-1945; (f) Thatagar, M. B.; Beckers, J.; Rothenberg, G. Green Chem. 2004, 6, 215-218.

5. (a) Park, S.; Kim, M.; Koo, D. H.; Chang, S. Adv. Synth. Catal. 2004, 346, $1638-$ 1640; (b) Garbacia, S.; Touzani, R.; Lavastre, O. J. Comb. Chem. 2004, 6, 297-300.

6. (a) Beletskaya, I. P.; Latyshev, G. V.; Tsvetkov, A. V.; Lukashev, N. V. Tetrahedron Lett. 2003, 44, 5011-5013; (b) Wang, L.; Li, P.; Zhang, Y. Chem. Commun. 2004, 514-515; (c) Wang, M.; Li, P.; Wang, L. Synth. Commun. 2004, 34, 2803-2812.

7. Li, J.-H.; Li, J.-L.; Want, D.-P.; Pi, S.-F.; Xie, Y.-X.; Zhang, M.-B.; Hu, X.-C. J. Org. Chem. 2007, 72, 2053-2057.

8. Biffis, A.; Scattolin, E.; Ravasio, N.; Zaccheria, F. Tetrahedron Lett. 2007, 48, 8761-8764

9. (a) Taillefer, M.; Ouali, A.; Renard, B.; Spindler, J.-F. Chem. Eur. J. 2006, 12, 53015313; (b) Ouali, A.; Laurent, R.; Caminade, A.-M.; Majoral, J.-P.; Taillefer, M. J. Am. Chem. Soc. 2006, 128, 15980-15981; (c) Ouali, A.; Taillefer, M.; Spindler, J.F.; Jutand, A. Organometallics 2007, 26, 65-74; (d) Ouali, A.; Spindler, J.-F.; Jutand, A.; Taillefer, M. Adv. Synth. Catal. 2007, 349, 1906-1916; (e) Monnier, F.; Taillefer, M. Angew. Chem., Int. Ed. 2008, 47, 3096-3099.

10. Kharasch, M. S.; Reinmuth, O. Grignard Reactions of Nonmetallic Substances; Prentice-Hall: New York, 1954. p 1257.

11. (a) Tamura, M.; Kochi, J. J. Am. Chem. Soc. 1971, 93, 1487-1489; (b) Tamura, M.; Kochi, J. J. Organometal. Chem. 1971, 31, 289-309; (c) Kochi, J. Acc. Chem. Res. 1974, 7, 351-360.

12. Molander, G. A.; Rahn, B. J.; Shubert, D. C.; Bonde, S. E. Tetrahedron Lett. 1983, 24, 5449-5452.

13. (a) Cahiez, G.; Chavant, P. Y.; Metais, E. Tetrahedron Lett. 1992, 33, 5245-5248; (b) Cahiez, G.; Marquais, S. Tetrahedron Lett. 1996, 37, 1773-1776; (c) Cahiez, G.; Avedissian, H. Synthesis 1998, 1199-1205; (d) Cahiez, G.; Habiak, V.; Duplais, C.; Moyeux, A. Angew. Chem., Int. Ed. 2007, 46, 4364-4366; (e) Cahiez, G.; Duplais, C.; Moyeux, A. Org. Lett. 2007, 9, 3253-3254.

14. (a) Fürstner, A.; Leitner, A.; Méndez, M.; Krause, H. J. Am. Chem. Soc. 2002, 124, 13856-13864; (b) Martin, R.; Fürstner, A. Angew. Chem., Int. Ed. 2004, 43, 39553957; (c) Fürstner, A.; Krause, H.; Lehmann, C. W. Angew. Chem., Int. Ed. 2006, 45, 440-444; (d) Scheiper, B.; Bonnekessel, M.; Krause, H.; Fürstner, A. J. Org. Chem. 2004, 69, 3943-3949.

15. (a) Dohle, W.; Kopp, F.; Cahiez, G.; Knochel, P. Synlett 2001, 1901-1904; (b) Duplais, C.; Bures, F.; Korn, T. J.; Sapountzis, I.; Cahiez, G.; Knochel, P. Angew. Chem., Int. Ed. 2004, 43, 2968-2970.

16. (a) Bedford, R. B.; Bruce, D. W.; Frost, R. M.; Goodby, J. W.; Hird, M. Chem. Commun. 2004, 2822-2823; (b) Bedford, R. B.; Bruce, D. W.; Frost, R. M.; Hird, M. Chem. Commun. 2005, 4161-4163; (c) Bedford, R. B.; Betham, M.; Bruce, D. W.; Davis, S. A.; Frost, R. M.; Hird, M. Chem. Commun. 2006, 1398-1400; (d) Bedford, R. B.; Betham, M.; Bruce, D. W.; Danopoulos, A. A.; Frost, R. M.; Hird, M. J. Org. Chem. 2006, 71, 1104-1110.

17. (a) Nakamura, M.; Hirai, A.; Nakamura, E. J. Am. Chem. Soc. 2000, 122, 978-979; (b) Nakamura, M.; Matsuo, K.; Ito, S.; Nakamura, E. J. Am. Chem. Soc. 2004, 126, 3686-3687; (c) Hatakeyama, T.; Nakamura, M. J. Am. Chem. Soc. 2007, 129, 9844-9845; (d) Guérinot, A.; Reymond, S.; Cossy, J. Angew. Chem., Int. Ed. 2007, 
46, 6521-6524; (e) Norinder, J.; Matsumoto, A.; Yoshikai, N.; Nakamura, E. J. Am. Chem. Soc. 2008, 130, 5858-5859.

18. Volla, C. M. R.; Vogel, P. Angew. Chem., Int. Ed. 2008, 47, 1305-1307.

19. For reviews on iron-catalysis, see: (a) Shinokubo, H.; Oshima, K. Eur. J. Org. Chem. 2004, 2081-2091; (b) Bolm, C.; Legros, J.; Le Paih, J.; Zani, L. Chem. Rev. 2004, 104, 6217-6254; (c) Fürstner, A.; Martin, R. Chem. Lett. 2005, 34, 624629; (d) Nečas, D.; Kotora, M. Chem. Listy 2006, 100, 967-973; (e) Enthaler, S.; Junge, K.; Beller, M. Angew. Chem., Int. Ed. 2008, 47, 2501-2947; (f) Enthaler, S.; Junge, K.; Beller, M. Angew. Chem., Int. Ed. 2008, 47, 3317-3321.

20. Carril, M.; Correa, A.; Bolm, C. Angew. Chem., Int. Ed. 2008, 47, 4862-4865.

21. A recent patent made similar kind of observations in the coupling of phenylacetylene with bromobenzene in the presence of $\mathrm{NaI}, \mathrm{Cu}(\mathrm{acac})_{2}$ and $\mathrm{FeCl}_{3}$. Taillefer, M; Xia, N; Ouali, A. PCT Int. Appl. WO 2008004088 A2 20080110; Chem. Abstr. 2008, 148, 144205.

22. (a) Plietker, B. Angew. Chem., Int. Ed. 2006, 45, 1469-1473; (b) Plietker, B. Angew. Chem., Int. Ed. 2006, 45, 6053-6056.

23. Taillefer, M.; Xia, N.; Ouali, A. Angew. Chem., Int. Ed. 2007, 46, 934-936.

24. (a) Correa, A.; Bolm, C. Angew. Chem., Int. Ed. 2007, 46, 8862-8865; (b) Bistri, O.; Correa, A.; Bolm, C. . Angew. Chem., Int. Ed. 2008, 47, 586-588; (c) Correa, A.; Carril, M.; Bolm, C. Angew. Chem., Int. Ed. 2008, 47, 2880-2883; (d) Bonnamour, J.; Bolm, C. Org. Lett. 2008, 10, 2665-2667; (e) Correa, A.; García Mancheño, O.; Bolm, C. Chem. Soc. Rev. 2008, 37, 1108-1117; (f) Correa, A.; Elmore, S.; Bolm, C. . Chem. Eur. J. 2008, 14, 3527-3529; (g) Correa, A.; Bolm, C. . Adv. Synth. Catal. 2008, 350, 391-394.
25. Shirakawa, E.; Yamagami, T.; Kimura, T.; Yamaguchi, S.; Hayashi, T. J. Am. Chem. Soc. 2005, 127, 17164-17165.

26. Kang, S. K.; Yoon, S. K.; Kim, Y. M. Org. Lett. 2001, 3, 2697-2699.

27. (a) Bohlmann, F.; Schoenowsky, H.; Inhoffen, E.; Grau, G. Chem. Ber. 1964, 97 794-800; (b) Kamata, K.; Yamaguchi, S.; Kotani, M.; Yamaguchi, K.; Mizuno, N. Angew. Chem., Int. Ed. 2008, 47, 2407-2410.

28. (a) Normant, J.-F.; Cahiez, G.; Bourgain, M.; Chuit, C.; Villieras, J. Bull. Soc. Chim Fr. 1974, 1656; (b) Crandall, J. K.; Collonges, F. J. Org. Chem. 1967, 41, 40894092; (c) Foulon, J. P.; Bourgain-Commerçon, M.; Normant, J.-F. Tetrahedron 1986, 42, 1389-1397.

29. Synergistic catalytic effect for $\mathrm{Cu}+\mathrm{Fe}$ compounds have been found for other reactions, see, for example: (a) the oxidation of $\mathrm{SO}_{2}$ : (a) Golodor, V. A.; Kashnikova, L. V. J. Mol. Catal. 1983, 19, 113-117; Rada, M. Water Science and Technology 1988, 20, 45-47; the oxidation of cyclohexane: (b) Schuchardt, U.; Pereira, R.; Krähembühl, C. E. Z.; Rufo, M.; Buffon, R. Appl. Catal. A: Gen. 1995 131, 135-141; CO hydrogenation: (c) Xu, R.; Ma, Z.; Yang, C.; Wei, W.; Sun, Y. Preprints of Symposia- ACS, Div-Fuel Chem. 2003, 48, 927-928; dechlorination of $\mathrm{CCl}_{4:}$ (d) Maithreepala, R. A.; Doong, R.-A. Environ. Sci. Technol. 2004, 38, 66766684; $\mathrm{CO}$ oxidation by $\mathrm{O}_{2}$ : (e) El-Shobaky, H. G.; Fahmy, Y. M. Mater. Res. Bull. 2006, 41, 1701-1713.

30. $\mathrm{Fe}(\mathrm{CO})_{5}$ and $\mathrm{CO}_{2}(\mathrm{CO})_{8}$ have shown synergistic catalytic effect in the carbonylation of aryl iodides: Brunet, J. J.; Taillefer, M. J. Organomet. Chem. 1990, 384, 193-197; see also: Brunet, J. J.; De Montauzon, D.; Taillefer, M. Organometallics 1991, 10, 341-346. 